\title{
New forms of immobilized active chlorine and its potential applications in medicine
}

\section{Volodymyr M. Toropin ${ }^{2}$ \\ Bohdan V. Murashevych ${ }^{1,2}$ \\ Dmytro O. Stepanskyi ${ }^{1}$ \\ Mykola V. Toropin'2 \\ Henadii M. Kremenchutskiy ${ }^{1}$ \\ Kostiantyn S. Burmistrov ${ }^{2}$}

${ }^{1}$ Dnipropetrovsk Medical

Academy of the Ministry

of Health of Ukraine,

9 Vernadsky St.,

Dnipro 49044,

Ukraine

${ }^{2}$ Ukrainian State University of Chemical Technology,

8 Gagarina Ave.,

Dnipro 49005,

Ukraine
T he search for new effective means for combating pathogenic microorganisms is one of the most important tasks of modern medicine. The main reason for the need for such studies is the obvious tendency to increase of the resistance of pathogenic microorganisms to the compounds used for these purposes, observed over the past few decades. Leading international organizations recognize the problem of the evolution of «superbacteria» as a global threat to humanity. Compounds of active chlorine are extremely effective biocidal agents. However, for the number of reasons, classic chlorine-active drugs (solutions of sodium hypochlorite, hypochlorous acid, chloramines, etc.) have limited use in medicine. This work is aimed at the study of the properties of new forms of active chlorine. Technology has been developed for the chemical immobilization of active chlorine donor groups on granular and fibrous polymer carriers. Polymers have been obtained, which contain 5-20\% of the active chlorine and are highly stable. It was shown that upon contact of such polymers with a medium containing ammonium salts or impurities of protein structure, emission of active chlorine occurs in an amount equivalent to the quantity of such impurities. Methods have been developed for the express manufacture of high-purity solutions of active chlorine (hypochlorous acid, chlortaurin) by activating these polymers with special activators. High antimicrobial activity of such solutions has been proved. It was shown that the polymers themselves also exhibit high microbicidal activity. The possibility of using fibrous forms of chlorine-active polymers as an antimicrobial component of a wound dressing has been investigated. The absence of toxicity of such dressings has been proved. It has been shown that the application of dressings on uninfected wounds speeds up the healing process. The application of dressings on infected wounds prevents the progress of inflammatory processes and significantly reduces the number of pathogenic microorganisms in wound secretions. Thus, synthesized polymers with immobilized active chlorine may be promising for use in water and air disinfection systems, for detoxification of hospital effluents, the rapid production of antimicrobial solutions, as well as for the manufacture of prolonged-action antiseptic wound dressings that protect wounds from secondary infection, that is especially important for military and disaster medicine.

Keywords: disinfection, antiseptics, active chlorine, immobilization, antiseptic solutions, antimicrobial activity, reparative activity, wound dressings.

For citation: Toropin VM, Murashevych BV, Stepanskyi DO, Toropin MV, Kremenchutskiy HM., Burmistrov KS. New forms of immobilized active chlorine and its potential applications in medicine. Journal of the National Academy of Medical Sciences of Ukraine. 2019;25(3):340-52
Bohdan V. Murashevych murashevych.b@gmail.com

The article was received on September 5, 2019 | For review, September 15, 2019 | Accepted for publication on September 17, 2019

\section{INTRODUCTION}

The efficacy of a complex of measures employed for the disinfection of premises, equipment, and tools, as well as that of air and water, aimed at achieving maximum possible reduction in the concentration of pathogens and their toxic metabolites, is the foundation of the proper functioning of all types of medical institutions. The need for the antiseptic treatment of a living organism's various surfaces in order to prevent the growth of microbes the negative biological and the prevention of chemical processes associated with such growth, is of particular importance. Such measures can be both prophylactic (prepation of a surgeon's hands, the postoperative treatment of seams, etc.) and therapeutic (the treatment of purulent wounds, infections of the nasal cavity and nasopharynx, etc.) [1].

Methods of disinfection and antiseptisis are extremely diverse, but the most common are those that rely on theuse of special chemicals [2]. This is due to the relative availability of 
such compounds and ease of their use, which allows organizing sufficiently effective complexes of measures for public and military and disaster medicine. Antimicrobial activity is manifested by various inorganic and organic chemicals, such as hydrogen peroxide, chlorine dioxide, iodine, salts of some metals, alcohols and phenols, acids and peroxy acids, quaternary ammonium salts and many others [3]. The impact of these substances is based on nonspecific chemical processes (oxidation, $\mathrm{pH}$ change, coagulation of proteins, impairment of permeability of the microbe's cell membrane), therefore giving them a wide range of antimicrobial activity, they are effective in quite high concentrations and their action is mainly a local one. In contrast, antibiotics, as a particular class of chemotherapeutic agents, have a more complicated mechanism of action and specific activity, but are effective at much lower concentrations and can act resorptively [4].

Despite the vast number of known antiseptic and antibiotic drugs, the search for new effective microbicidal substances has not lost its topicality. This is associated primarily with the evolution of microorganisms, thereby developing resistance to such compounds, especially to antibiotics. A trend that can be observed as of late is an increase of the number of multiresistant strains, so-called superbugs $[5,6]$. At the same time, while previously such microbes were mainly hospitalacquired, their presence outside medical institutions has now been registered [7]. And the situation is becoming more complicated because some microorganisms are resistant not only to antibiotics, but also to some classical antiseptics, as for example, alcohols [8]. This is due, inter alia, to an increase in the ability of superbugs to rapidly form biofilms, which significantly suppresses their diffusion and helps reduce their concentration to a value that is safe for the colony [9]. Superbugs are a recognized a global problem, and many international organizations and scientific groups, including those that are WHO- and UN-related, such as GLASS, GARDP, IACG, and others are currently working on research aimed at identifying the processes involved in their development and on finding new ways to combat them $[10,11]$. It is therefore apparent that the development of new disinfectants and antiseptics is of extreme importance to modern chemistry and medicine.

\section{ACTIVE CHLORINE-BASED ANTISEPTIC DRUGS}

Chlorine-based drugs are a particular class of disinfectants, some of which are also used as antiseptics. Sodium hypochlorite $(\mathrm{NaClO})$ is the most well-known and easilu available of them, but many other substances of this class are also used widely: calcium hypochlorite, hypochlorous acid, chloramines, chloroisocyanurates, chlorohydantoins, etc. The mechanism of antimicrobial action of these drugs is based on the high oxidative properties of hypochlorite ion, which is formed during their dissolution, as well as free radicals, which are products of its decomposition, due to which the structure of the cell membrane of microorganisms is disrupted [12]. Compared to other antiseptics, chlorineactive drugs have a more pronounced antimicrobial effect and have a greater impact on biofilms. Hypochlorous acid $(\mathrm{HClO})$ has the highest activity in this group, and due to its small size is also able to penetrate into the cell, disrupting the functioning of its organelles [13]. In addition, it is also capable of neutralizing most toxins, including botulotoxin and ricin [14]. Besides a few reports on the decrease in the effectiveness of chlorine-active drugs in recent years [15], there are no examples of microorganism's resistance to hypochlorous acid. It is important to emphasize that hypochlorous acid and some of its derivatives (for example, $\mathrm{N}$-chlorotaurine) are biogenic substances that are synthesized in the body as a response to inflammatory processes and have been found in many live cells (neutrophils, hepatocytes, etc.) [16]. This provides a number of significant advantages, the most important of which is the existence of well-established mechanisms of neutralization and excretion of active chlorine inside the living organisms and the absence of allergic reactions to them. However, the use of chlorine-active drugs, first of all, hypochlorous acid, in modern medicine is limited by a number of disadvantages. The main one of them being its is very low stability. Even at room temperature, in contact with air or under the sunlight, they decompose rapidly, mainly with the formation of oxygen or by a chlorate mechanism. Preparations of N-chlorothaurine, such as «Neoreodes», are more stable, but they also require special storage conditions [17]. Drugs, which contain active chlorine in the form of chloramines or acid chloramides (Chloramines $\mathrm{B}, \mathrm{T}, \mathrm{HB}$, chlorine derivatives of hydantoin and cyanuric acid) have relatively high stability and, more importantly, can exist in a solid state. However, they do contain a number of additional substances that reduce their efficiency and can accumulate in the body and in the environment causing allergic reactions, etc. Ballast substances present in industrial-made solutions of sodium hypochlorite related to the technology of their production (sodium hydroxide, dissolved chlorine) make it impossible to use it as an antiseptic at all. There are special devices - electrolyzers, which allow obtaining hypochlorite solutions «in situ» [18], but the highest concentration of «pure» solutions obtained in such a manner (i.e. those containing only impurities of sodium chloride) is about $0.1 \%$; electrochemically generated solutions with higher hypochlorites concentration often containing significant amounts of toxic chlorates. Moreover, such technologies require special equipment and reactants, which is inconvenient in emergencies. It has to be noted that solutions of sodium hypochlorite can be converted into solutions of more active hypochlorous acid by acidifying them to $\mathrm{pH} 4.5$, but greatly.reduces their stability Only recently literature has appeared, stating that some progress has been made in the manufacture of stable solutions of hypochlorous acid, which was made possible by the complex composition of excipients. Thus, the pharmaceutical company NovaBay (USA) produces solutions of hypochlorous acid with a concentration of 0.01-0.02 \% under the trademarks «Neutro Phase», «Neutrox» [19]. Briotech Inc (USA) produces «Briotech Topical skin spray» which is a $0.02 \%$ solution of this acid [20]. Pharmaceutical company «Sonoma Pharmaceuticals» (USA) produces a line of drugs: «Microcyn», «Epicyn», «Levicyn», «Acuicyn» and others [21]. Redox Technology LTD (Russia) produces $0.15 \%$ solution «Doctor Chistoteloff» [22]. All of these drugs are recommended for the treatment of chronic ulcers, diabetic foot ulcers, infected bedsores, first- and second-degrees burns, for the prophylactic treatment of surgical and traumatic wounds, 
etc. But their efficiency during contact with the wound is timelimited due to the rapid decomposition of hypochlorous acid. Agents are available to permanently maintain the concentration of hypochlorous acid in the wound, such as the bioelectric bandages «Procellera» and «Posifect RD» [23], although their use is inconvenient and expensive. Therefore, the synthesis of chlorine-containing materials which are capable of gradually releasing active chlorine, when in contact with biological ambient is very important.

\section{IMMOBILIZED FORMS OF ACTIVE CHLORINE}

Numerous attempts have been made to immobilize functional groups - donors of active chlorine onto polymeric carriers, in order to increase the stability of chlorine-active drugs, as well as to give them a form that is convenient for use in new fields. The main idea of such studies is to embed into the structure of a polymer carrier, groups that would contain exactly chemically bounded active chlorine and could easily emit it in one form or another into the treated environment. It should be emphasized that the simple impregnation of any polymer with a solution of active chlorine or the application of a solid chlorine-active substance on a carrier not only does not allow to meet the goal but, on the contrary, instead of increasing the stability, leads to its faster decomposition. The first such work were initiated by Nakamura [24]. He synthesized N-chlorosulfonamides and $\mathrm{N}, \mathrm{N}$-dichlorosulfonamides immobilized on linear polystyrene. It has been proven that when immersed in water, these granular compounds exhibit bactericidal properties. But because of their ability to swell and become a gel, they appeared to be unsuitable for use. Emmerson [25, 26] obtained N-chlorosulfonamides immobilized on a styrene copolymer with divinylbenzene, which were devoid of this disadvantage. When immersed in water, they were found to be capable of releasing more than 1 $\mathrm{mg} / \mathrm{l}$ of active chlorine, which was sufficient to provide some bactericidal properties. Bogoczek and Kociolek-Balawejder [27, 28] synthesized immobilized sodium $\mathrm{N}$-chlorosulfonamide on a matrix of macroporous crosslinked styrene copolymer with divinylbenzene. They have studied its stability, bactericidal, cation-exchange and oxidizing properties, which made it possible to suggest the use of these compounds to neutralize a number of toxic substances (sulfides, nitrites, arsenites, cyanides, etc.) $[29,30]$. All of the above compounds had a granular form and were considered by the authors purely as potential agents for disinfecting and optimizing the chemical composition of drinking water. The prospects for their medical use had not been investigated. In addition, the technology for manufacturing such materials does not allow obtaining products with a sufficiently developed surface and regulate the quantity of the active groups and kinetic characteristics of the active chlorine emission process into the treated environment.

More suitable for medical use are fibrous materials with immobilized active chlorine. Having vast interfacial surface and comfortable «soft» shape, they are convenient for use in the manufacture of special clothing, antiseptic wipes, and, most importantly, as active components of medical antiseptic dressings. Chlorine-active compounds (chlorhydantoin, chlorisocyanurate and chloramide), grafted on fibrous and tissue materials of natural and synthetic origin, have been described [31-33]. It has been reported that nanofibrous materials can be obtained by the method of jet electrospinning of solutions of the $\mathrm{N}, \mathrm{N}$-dichlorosulfonamide immobilized on polystyrene. The positive results of the test of the synthesized material for neutralization of 2-chloroethyl ethyl sulfide (an analog of yperite) have been obtained, so such material can be used for the manufacture of protective clothing against toxic substances of this type [34]. Numerous studies on the antimicrobial properties of such materials confirm their pronounced antiseptic activity and mean that they are promising for use in medicine [35]. At the same time, there are a number of obvious criteria that these materials must meet. Carrier polymers shall not contain impurities of monomers, polymerization initiators and other low molecular substances that may be released into the environment with active chlorine. Simultaneously, they must have appropriate physical and mechanical properties (density, humidity, strength, specific surface area, etc.). In view of the rather strict conditions of the necessary polymeranalogical transformations, they must be chemically stable and not hydrolyze in highly alkaline and highly acidic solutions. In order to reduce the environmental burden, it is also desirable that the carriers are either easily degradable or regenerable. The grafted donor groups should remain neutral after the release of the active agent. Finally, synthesis technologies must ensure the economic competitiveness of such materials in comparison with their traditional functional analogs.

\section{SYNTHESIS OF NEW FORMS OF CHLORINE-ACTIVE POLYMER MATERIALS AND EMISSION OF ACTIVE CHLORINE FROM THEM}

Since 2011, we have been researching the synthesis of new forms of immobilized active chlorine, which are convenient for use in medicine, specifically for the rapid disinfection of water and air, detoxification of hospital effluents, non-electrochemical production of high-purity chlorine-active solutions and for the manufacture of components of antiseptic wound dressings. The following materials were first used by us as polymeric carriers: granular styrene copolymer with divinylbenzene produced by SE «Smoly» (Ukraine) of gel and macroporous structure and FIBAN K-1 cation exchanger in staple form and in the form of non-woven fabric (synthesized at the Institute of PhysicoOrganic Chemistry of the National Academy of Sciences of the Republic of Belarus) [36]. FIBAN K-1 is a copolymer of styrene with divinylbenzene, grafted by special radiation polymerization technology to polypropylene filament with further sulfonation. Such polymers are manufactured industrially, they are standardized and have corresponding certificates [37]. The carriers we have chosen fully meet the above-mentioned requirements: they do not contain low molecular impurities, are resistant to concentrated acids and alkalis, are regenerable and provide a moderately low level of operating costs. Immobilization of «active chlorine» onto these polymeric carriers has been carried out by us according to the following general schemes (Schemes 1, 2).

As a result of these chemical transformations, we have obtained polymeric materials with a range of ( 5 to $15 \mathrm{wt}$. \%) concentrations of active chlorine in the form of grafted $\mathrm{N}$-chlorosulfonamide 

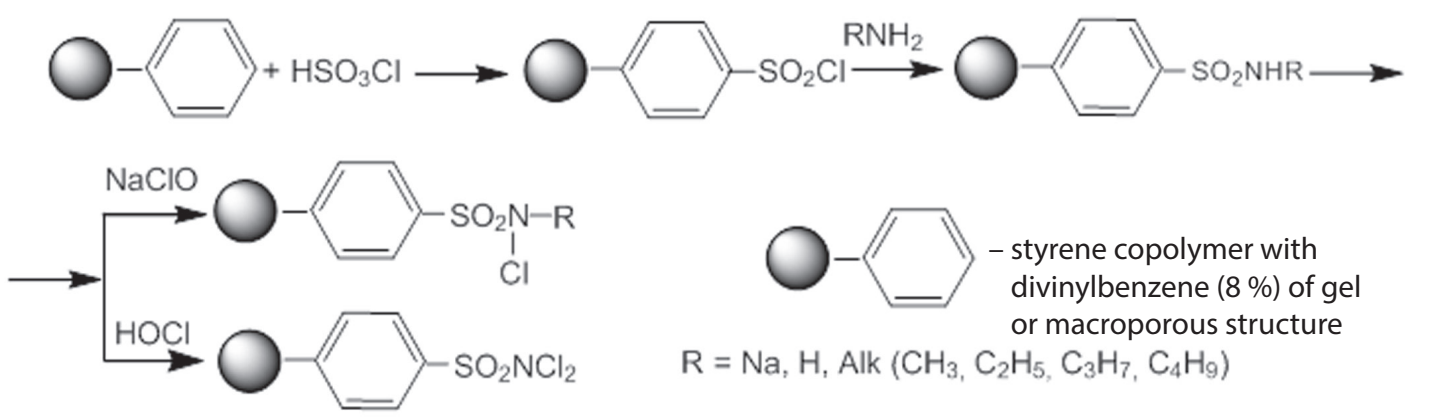
$\mathrm{R}=\mathrm{Na}, \mathrm{H}$, Alk $\left(\mathrm{CH}_{3}, \mathrm{C}_{2} \mathrm{H}_{5}, \mathrm{C}_{3} \mathrm{H}_{7}, \mathrm{C}_{4} \mathrm{H}_{9}\right)$
Scheme 1.

Synthesis and structure of granular immobilized $\mathrm{N}$-chlorosulfonamides

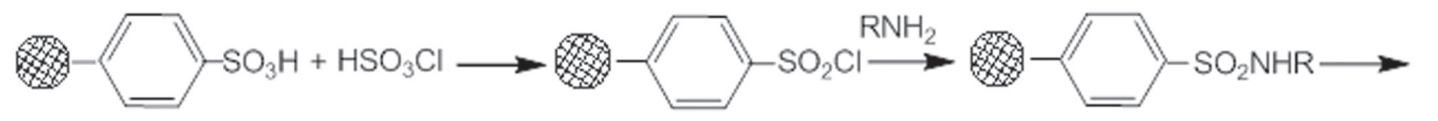<smiles>[R]NOS(=O)(=O)c1ccc(C#Cc2ccc([As](=O)(=O)O[Na])cc2)cc1</smiles><smiles>C#CC(=C)c1ccccc1</smiles>

- copolymer of styrene with divinylbenzene (1\%), grafted to polypropylene filament
Scheme 2.

Fibrous forms of immobilized $\mathrm{N}$-chlorosulfonamides grafted onto polypropylene

(H-form and Na-form), N,N-dichlorosultonamide and $\mathrm{N}$-chloro-N-alkylsulfonamide functional groups. The granular forms of the synthesized polymers are convenient for use in water treatment, stale fibrous forms due to the large surface area and low flow resistance can be used to purify the air, and non-woven fabrics are planned to be used in the making of medical dressings (Fig. 1).

It should be noted that in all cases there is a certain amount of sulfonic acid groups, which additionally provide the ionexchange properties of the materials and the possibility of their further modification, for example, adsorption of aluminum cations to give a hemostatic effect to wound dressings. The main physicochemical characteristics of some of the synthesized materials are shown in Tables 1 and 2 .

We have investigated the emission of active chlorine from synthesized materials into aqueous ambients. It has been found that when immersed granule samples in distilled water slow hydrolysis of functional groups occurs and the concentration of active chlorine $3-8 \mathrm{mg} / \mathrm{dm}^{3}$ is reached $[38,39]$. In the case of staple-fibrous and non-woven forms the concentration of the solutions was even lower $-2-4 \mathrm{mg} / \mathrm{dm}^{3}$. These quantities are sufficient to purify water from Escherichia coli and some other microorganisms, so these materials can be used to prevent microbial contamination of purified water during storage [40]. But to reach powerful antiseptic properties, this concentration is not enough. To increase the concentration of active chlorine

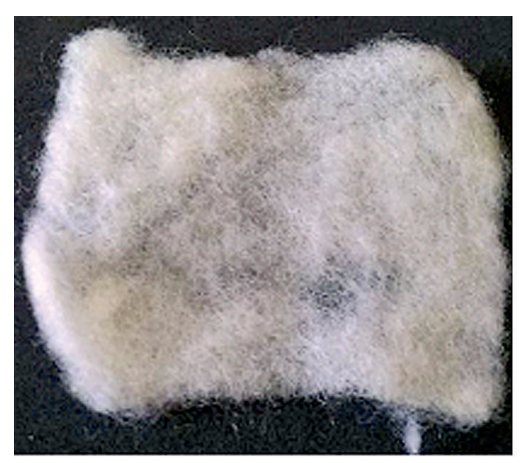

Non-woven fabric

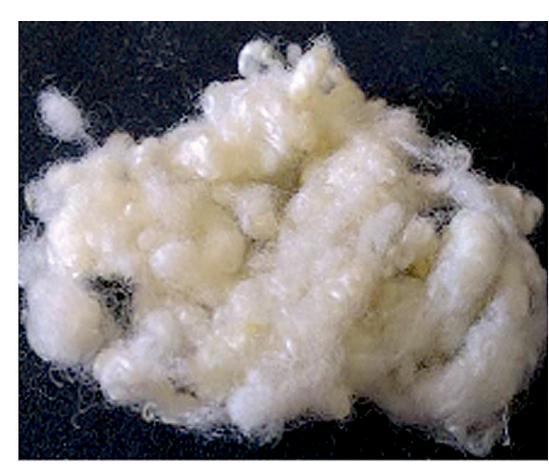

Staple fibrous form
TABLE 1. PHYSICO-CHEMICAL CHARACTERISTICS OF GRANULAR FORMS OF SODIUM N-CHLOROSULFONAMIDE

\begin{tabular}{|c|c|}
\hline Property & Value \\
\hline Concentration of active chlorine & $5-11 \%$ \\
\hline Humidity of air-dry product & $20-23 \%$ \\
\hline The average size of the granules & $0,5 \mathrm{~mm}$ \\
\hline The presence of free $\mathrm{SO}_{3} \mathrm{H}$-groups & $0,27-0,3 \mathrm{mg}$-eq./g \\
\hline Resistance to heat without decomposition & up to $90^{\circ} \mathrm{C}$ \\
\hline
\end{tabular}

TABLE 2. PHYSICO-CHEMICAL CHARACTERISTICS OF THE NON-WOVEN FIBROUS FORM OF SODIUM $\mathrm{N}-\mathrm{CHLOROSULFONAMIDE}$

\begin{tabular}{|c|c|}
\hline Property & Value \\
\hline Concentration of active chlorine & $6-11 \%$ \\
\hline Humidity of air-dry product & $4-8 \%$ \\
\hline Monofilament diameter & $40-50 \mathrm{mcm}$ \\
\hline Surface density & $250-350 \mathrm{~g} / \mathrm{m}^{2}$ \\
\hline Fibre thickness & $2-3 \mathrm{~mm}$ \\
\hline The presence of free $\mathrm{SO}_{3} \mathrm{H}$-groups & $0,5-0,7 \mathrm{mg}-\mathrm{eq} . / \mathrm{g}$ \\
\hline Water absorption & $820 \%$ \\
\hline Water absorption capacity & $115 \%$ \\
\hline Resistance to heat without decomposition & up to $100{ }^{\circ} \mathrm{C}$ \\
\hline
\end{tabular}

Fig.1.

The appearance of the synthesized materials 


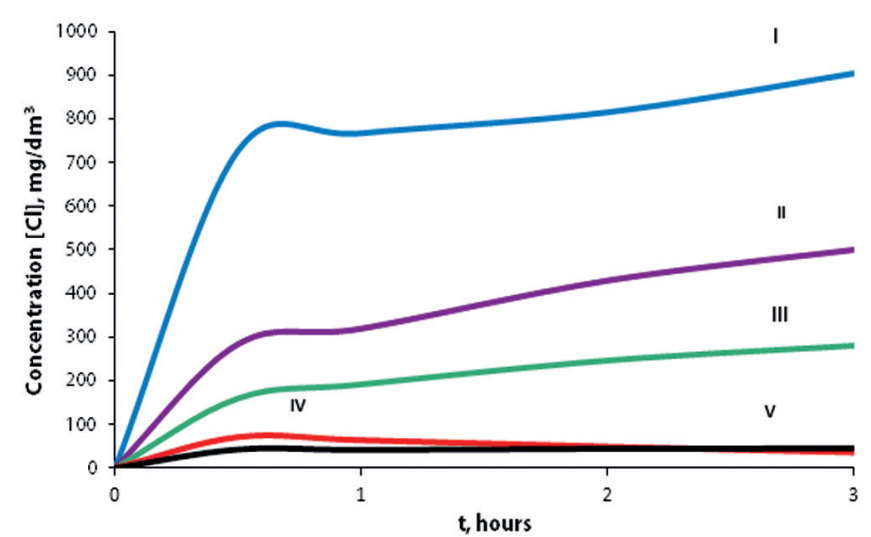

Fig. 2. Sodium N-Chlorosulfonamide, immobilized on the granule of gel structure. The dependence of the active chlorine concentration on the exposition time and the activator used: I - taurine, II - sulfamic acid, III - ammonia water solution, IV - ammonium chloride, V - KU2-8 ammonium form.

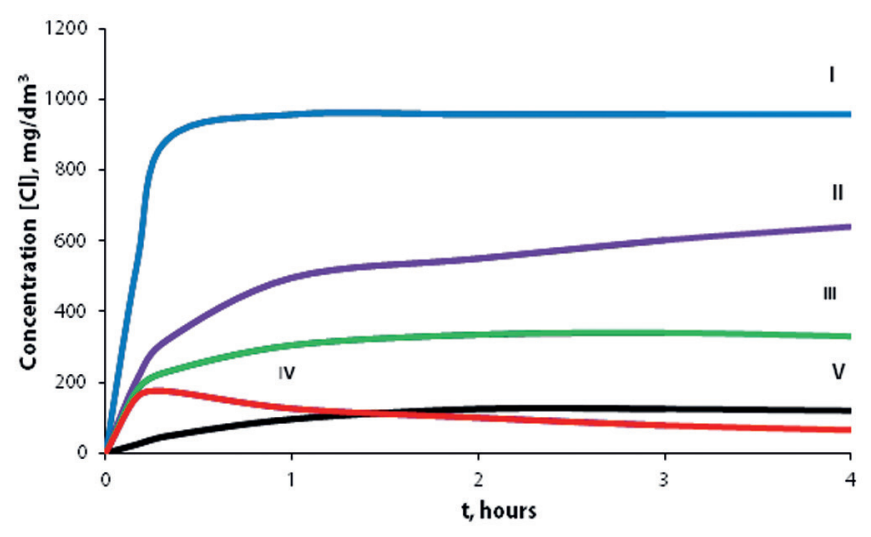

Fig. 3. Sodium N-Chlorosulfonamide, immobilized on the fibrous material. The dependence of the active chlorine concentration on the exposition time and the activator used: I - taurine, II - sulfamic acid, III - ammonia water solution, IV - ammonium chloride, $\mathbf{V}$ - ammonium form of FIBAN K-1

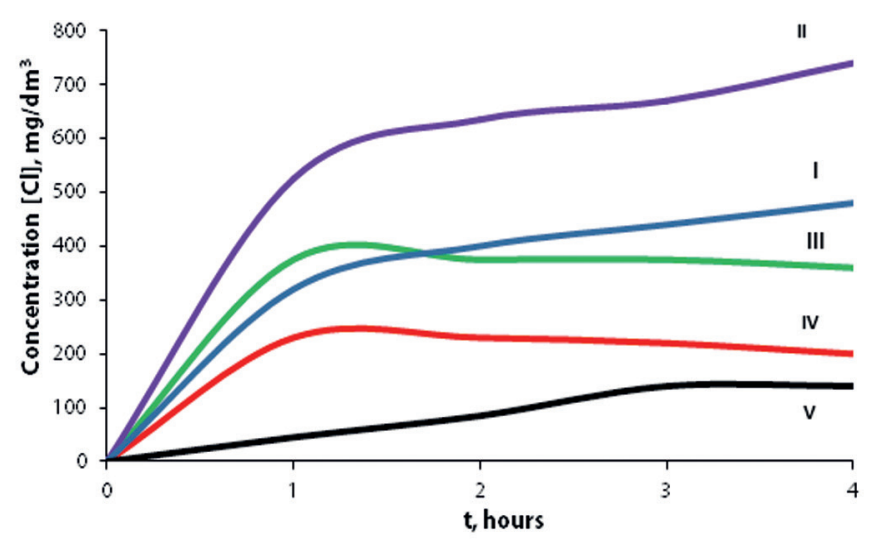

Fig. 4. N,N-dichlorosulfonamide, immobilized on the fibrous material. The dependence of the active chlorine concentration on the exposition time and the activator used: I - taurine, II - sulfamic acid, III - ammonia water solution, IV - ammonium chloride, $\mathbf{V}$-ammonium form of FIBAN K-1 in solutions of common chlorosulfonamides activators are being used [38]. As activators, we tested a number of nitrogencontaining compounds - ammonium chloride, KU-2-8 cation exchanger in ammonium form, ammonia solution, sulfamic acid and taurine. For this purpose, a sample of polymers containing $2 \mathrm{mmol}$ of active chlorine was immersed in distilled water containing $4 \mathrm{mmol}$ of activator. The concentration of the solution at different points in time was measured by the standard method [41]. Generalized data of the active chlorine emission process are presented in the form of kinetic curves (Fig. 2-4).

It can be seen, that the addition of any of the above activators to all forms of polymers allows to increase the concentration of active chlorine in solution compared to distilled water. The most effective activator of $\mathrm{N}$-chlorosulfonamide materials appeared to be taurine, which allowed to obtain solutions with a concentration of about $950 \mathrm{mg} / \mathrm{dm}^{3}$ within 30 minutes. Active chlorine in such solutions exists in the form of $\mathrm{N}$-chlorotaurine. The emission rate from staplefibrous forms is higher than that of granules and nonwovens. Some peculiarities of activation of $\mathrm{N}, \mathrm{N}$-dichlorosulfonamide materials have been revealed: the processes of active chlorine emission from them are much slower in comparison with the immobilized N-chlorosulfonamides, and the more effective activator is sulphamic acid rather than taurine. This is due to the formation of $\mathrm{N}, \mathrm{N}$-dichlorothaurine in these solutions, and not $\mathrm{N}$-chlorotaurine, which has been proved by the method of UV spectroscopy. It is known that solutions of both taurine derivatives have high antiseptic properties [42, 43]. In contrast to the preparations of chlortaurines, made according to the classical scheme by dissolving taurine in sodium hypochlorite, the solutions prepared by our method contain much fewer impurities and, therefore, are much more stable. When polymers are activated with ammonium salts, active chlorine in solution exists in the form of a mixture of hypochlorous acid and monochloramine; when $\mathrm{pH}$ lowers, the formation of molecular chlorine is possible, too. Such solutions have more powerful oxidizing properties but are less stable. If the polymer is activated with ammonia, ammonium hypochlorite is formed [38]. We have discovered that, besides the chemically pure activators used, the release of active chlorine into the solution causes the adding of other substances: bread mold, «bloomed» water, urine, blood, etc. Wherein, in the absence of such impurities during the storage of materials in water, the release of active chlorine in a significant amount was not observed for months. Thus, the synthesized chlorine-active polymers can be used for the rapid preparation of high-purity solutions of active chlorine compounds with different concentrations and properties depending on the intended purpose. In addition, it is possible to use such materials for rapid water disinfection.

We have shown that after prolonged storage of all forms of polymers in a solution containing an excess of activator, functional groups-donors of active chlorine are absent in them, that is, the process of active chlorine emission is complete and depends only on the quantity of contaminants trapped into the solution. After washing the «used» material with water and appropriate organic solvents, treating with the solution of sodium hypochlorite and drying, the content of active chlorine in the material is completely restored. This means 
that the carrier-groups were not destroyed during exploitation, so the materials can be easily regenerated and reused. As for the stability of the synthesized materials during storage, it is extremely high. Without special storage conditions, the loss of active chlorine for granule forms is about $2 \%$ per year, staplefibrous and non-woven forms - about $5 \%$ per year. When stored in closed containers in a place protected from direct sunlight, this value is less than $1 \%$.

\section{ANTIMICROBIAL ACTIVITY OF SOLUTIONS OBTAINED FROM SYNTHESIZED POLYMERS}

We have investigated the in vitro antimicrobial properties of active chlorine solutions obtained from granular (because of their highest stability) and staple (because of the highest emission rate of active chlorine) forms of the synthesized immobilized N-chlorosulfonamides. For this purpose, by activating sodium $\mathrm{N}$-chlorosulfonamide of macroporous structure by ammonium chloride solution has been obtained with an active chlorine concentration $30 \mathrm{mg} / \mathrm{dm}^{3}$, and from the staple form of sodium $\mathrm{N}$-chlorosulfonamide with the same activator - a solution with concentration $100 \mathrm{mg} / \mathrm{dm}^{3}$. The tests have been carried out on test cultures of conditionally pathogenic microorganisms. The test cultures were added to these solutions at a concentration of $108 \mathrm{CFU} / \mathrm{ml}$ and left for $0,1,5,10$ and 20 minutes, after which viable cells were determined by the method of dilution and seeding on dense culture medium in Petri dishes. The latter were incubated in a thermostat at $37{ }^{\circ} \mathrm{C}$ for 24 hours, then the calculation of colony-forming units per $1 \mathrm{ml}$ was being made. The results are shown in Table 3.

It can be seen, that the solution with concentration of $30 \mathrm{mg} / \mathrm{dm}^{3}$ inactivates all the tested microorganisms in 20 minutes, and more the concentrated - in 5 minutes, which confirms the high antiseptic activity of chlorine-active solutions obtained from our polymers.
Separately, we have investigated solutions of $\mathrm{N}$-chlorotaurines obtained by the activation of chlorine-containing polymers by taurine. The $450 \mathrm{mg} / \mathrm{dm}^{3} \mathrm{~N}$-chlorotaurine solution obtained from granular macroporous sodium N-chlorosulfonamide suppresses Staphylococcus aureus (MRSA) by $85 \%$ after 30 minutes of exposition (by the above procedure). This fully confirms the data of the scientists at NovaBay Pharmaceuticals [44]. The antimicrobial properties of the $970 \mathrm{mg} / \mathrm{dm}^{3}$ $\mathrm{N}$-chlorotaurine solution obtained from the staple form of $\mathrm{N}$-chlorosulfonamide sodium have been investigated by another method. The culture medium (meat-peptone agar) have been placed in Petri dishes and the sowings have been lawned with 1 billion suspensions of diurnal test cultures of conditionally pathogenic microorganisms. A hollow cylinder was being superimposed on the medium and $0.1 \mathrm{~cm}^{3}$ of the test solution was being carried inside it. After thermostating the dish at $37^{\circ} \mathrm{C}$ for 24 hours, the zones of inhibition of the test microorganisms have been measured. The results are shown in Table 4.

Thus, the solutions obtained by the activation of the chlorine-active polymers by taurine also show pronounced antimicrobial properties, albeit at a higher concentration than the solutions activated by ammonium chloride. This is explained by the lower redox potential of N-chlorotaurine comparing to hypochlorous acid and inorganic hypochlorites. At the same time, N-chlorotaurine has additional positive effects: it does not affect healthy tissues and is an inhibitor of collagenase and elastase [45]. Therefore, it is appropriate to use such solutions for the treatment of infected and purulent wounds.

\section{ANTIMICROBIAL PROPERTIES OF POLYMERS WITH IMMOBILIZED ACTIVE CHLORINE}

To determine the possibility of using synthesized chlorine-active polymers as components of wound dressings, it was necessary to investigate their antimicrobial properties directly [46, 47]. For this purpose, two samples of non-woven materials were

TABLE 3. INVESTIGATION OF ANTIMICROBIAL PROPERTIES OF ACTIVE CHLORINE SOLUTIONS OBTAINED FROM IMMOBILIZED SODIUM N-CHLOROSULFONAMIDES

\begin{tabular}{|c|c|c|c|c|c|c|c|c|}
\hline \multirow{4}{*}{ Microbe } & \multicolumn{8}{|c|}{ Exposition time $\tau$, minutes } \\
\hline & \multicolumn{5}{|c|}{ Conc. $30 \mathrm{mg} / \mathrm{dm}^{3}$} & \multicolumn{3}{|c|}{ Conc. $100 \mathrm{mg} / \mathrm{dm}^{3}$} \\
\hline & $\mathbf{0}$ & 1 & 5 & 10 & 20 & 0 & 1 & 5 \\
\hline & \multicolumn{8}{|c|}{ The number of microorganisms after exposition in an active chlorine solution, $\mathrm{CFU} / \mathrm{ml}, \mathrm{t}=+4^{\circ} \mathrm{C}$} \\
\hline A. viridans & 108 & 107 & $2,9 \times 104$ & $2,3 \times 102$ & 0 & 108 & 107 & 0 \\
\hline E. coli & 108 & 108 & 0 & 0 & 0 & 108 & 108 & 0 \\
\hline B. Subtilis & 108 & 108 & $3,4 \times 106$ & 106 & 0 & 108 & 108 & 0 \\
\hline C. albicans & 108 & 108 & $2 \times 104$ & 0 & 0 & 108 & 108 & 0 \\
\hline P. aeruginosa & 108 & 108 & $2 \times 104$ & 0 & 0 & 108 & 108 & 0 \\
\hline S. aureus & 108 & 108 & $2 \times 104$ & 0 & 0 & 108 & 108 & 0 \\
\hline K. pneumoniae & 108 & 106 & 0 & 0 & 0 & 108 & 106 & 0 \\
\hline
\end{tabular}

TABLE 4. INVESTIGATION OF ANTIMICROBIAL PROPERTIES OF THE N-CHLOROTAURINE SOLUTION OBTAINED FROM IMMOBILIZED SODIUM N-CHLOROSULFONAMIDES

\begin{tabular}{|l|c|c|c|c|c|c|}
\hline Microbe & E.coli & C. albicans & P. aeruginosa & S. aureus & K. pneumoniae & S. epidermidis \\
\hline Zone of inhibition, $\mathrm{mm}$ & 21 & 18 & 19 & 23 & 18 & 22
\end{tabular}


chosen: sodium $\mathrm{N}$-chlorosulfonamide (concentration of active chlorine $10 \%$, thickness $2.5 \mathrm{~mm}$, surface density $340 \mathrm{~g} / \mathrm{m}^{2}$ ) and $\mathrm{N}, \mathrm{N}$-dichlorosulfonamide (concentration of active chlorine $16 \%$, thickness $2.5 \mathrm{~mm}$, surface density $340 \mathrm{~g} / \mathrm{m}^{2}$ ). The study was performed by the method of «agar plates». Flasks with melted and cooled to $45{ }^{\circ} \mathrm{C}$ meat-peptone agar were contaminated with suspensions of test-strains of the most common agents of wound infection - E. coli, S. aureus and C. albicans. The microbial load was $1 \times 10^{7} \mathrm{CFU} / \mathrm{cm}^{3}$. Then $20 \mathrm{~cm}^{3}$ of the medium was being poured into Petri dishes and left to full crystallization. Then, samples of the investigated materials, $2 \times 2 \mathrm{~cm}$ in size, were being placed on the surface. Dishes (three parallels for each sample) were incubated for 24-48 hours at $37{ }^{\circ} \mathrm{C}$. After incubation, the zones of inhibition around the samples were being measured. In such an experiment, the growth inhibition in all cases was observed only directly below the samples. We have suggested that this is because of the fibrous, fluffy structure of the polymers, which does not provide effective contact with the culture medium and impedes the diffusion of active chlorine into it. Therefore, the method of «agar plates» was being modified by us thusly: samples of polymers were immersed into melted agar so that the culture medium covered their sides. All other operations remained unchanged. In such an experiment, wide zones of microbial growth inhibition around the samples were observed in all cases (Table 5, Fig. 5).

TABLE 5. ZONES OF INHIBITION AROUND POLYMER SAMPLES

\begin{tabular}{l|c|c|}
\multirow{2}{*}{ Test-strain } & \multicolumn{2}{|c}{$\begin{array}{c}\text { Zone of inhibition (average of three } \\
\text { parallels), } \mathbf{m m}\end{array}$} \\
\cline { 2 - 3 } & $\begin{array}{c}\text { Sodium } \\
\text { N-chlorosulfonamide }\end{array}$ & $\begin{array}{c}\text { Sodium N,N- } \\
\text { dichlorosulfonamide }\end{array}$ \\
\hline E.coli & 6,5 & 12,0 \\
S.aureus & 20,5 & 30,0 \\
C.albicans & 5,0 & 40,0
\end{tabular}

As can be seen, the inhibition zones around N, N-dichlorosulfonamide samples are much wider than those around sodium $\mathrm{N}$-chlorosulfonamide. This is due to the higher emission rate of active chlorine. It is worth emphasizing the especially pronounced effect of the materials on S. aureus, which is known to be one of the most common and dangerous «hospital» bacteria. Later, similar tests have been carried out with respect to other microorganisms, and they also had positive results [48].

Thus, immobilized forms of active chlorine being wetted by the ambient containing free amino groups (for example, in the composition of amino acids), ammonium salts or other activators, provide the emission of active chlorine in quantities which are sufficient for effective antiseptic treatment of this ambient. It can be assumed that the materials will act similarly when in contact with the skin of the living organism: in the case of dry uninjured skin these materials will remain inactive, and in the case of contact with the wound (blood, wound exudate) the effective disinfection of it will occur.

\section{INVESTIGATION OF TOXICITY, REPARATIVE AND ANTIMICROBIAL ACTIVITY OF SYNTHESIZED POLYMERS in vivo}

Modern wound dressings must have a regenerative and antimicrobial effect and not cause tissue irritation. To evaluate the efficiency of antiseptic wound dressings, which contain the obtained polymers with immobilized active chlorine as the main component, we have conducted a number of investigations on laboratory animals. All the rules of the European Convention for the Protection of Vertebrate Animals used for Experimental and other Scientific Purposes have been complied with during the study. Test samples of non-woven forms of immobilized sodium $\mathrm{N}$-chlorosulfonamide (6\% active chlorine content) and $\mathrm{N}, \mathrm{N}$-dichlorosulfonamide (9\% active chlorine content) were being used as dressings. To prevent the microfibers of the polymers from adhering to the wound surface, the samples were packed in $1.5 \times 1.5 \mathrm{~cm}$ cases made of polypropylene fabric produced by the spunlace technology. Such fabrics are hypoallergenic, chemically resistant, have appropriate mechanical properties and do not interfere with the diffusion process of active chlorine through themselves. They are now widely used in medicine for the manufacture of bandages and napkins.

Investigation of the toxicity of such dressings in a single application has been studied by applying them to the skin of laboratory rats weighing 200-220 g and rabbits weighing $2.0-2.5 \mathrm{~kg}$. Applications were performed on specially cut sections of animal skin. The number of animals in the experimental groups was 16 rats and 5 rabbits. In addition, the active substance $-0.06 \%$ solution of sodium hypochlorite (obtained by dilution of the drug «Vetox-1000» [49]) with

Fig. 5. Zones of inhibition around the sample of sodium N-chlorosulfonamide

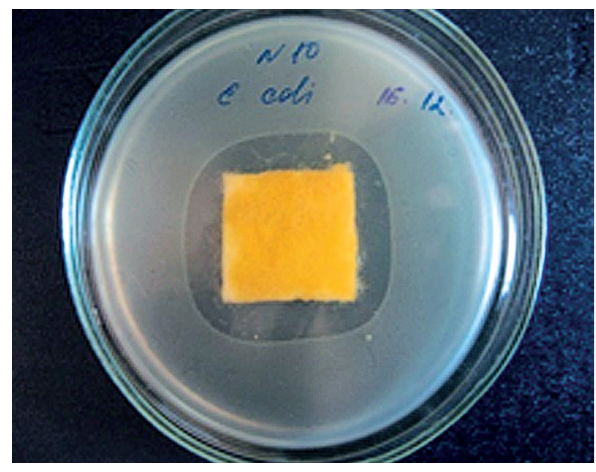

E.coli

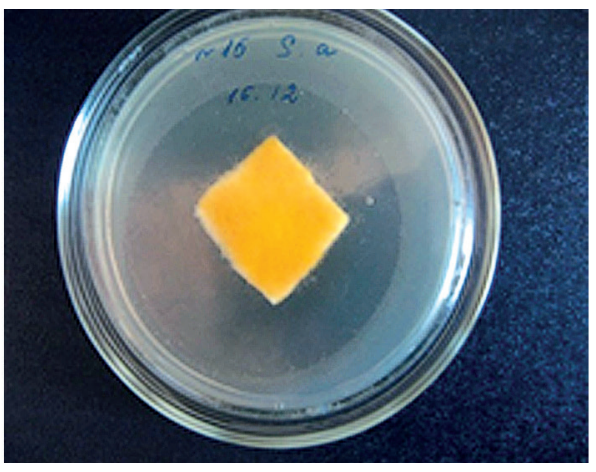

S.aureus

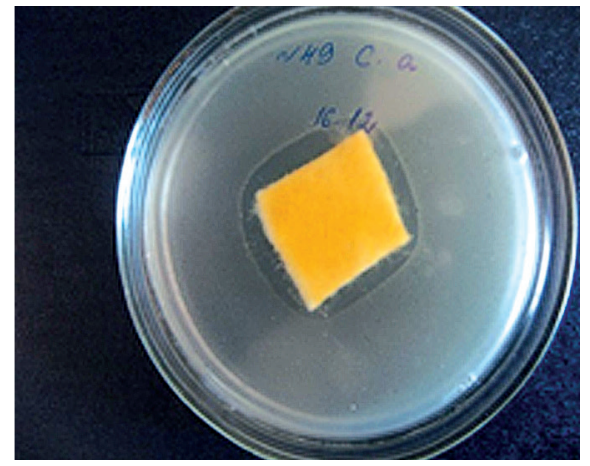

C.albicans 
TABLE 6. MASS RATIOS (\%) OF INTERNAL ORGANS OF RATS AFTER A SINGLE CUTANEOUS APPLICATION OF TEST SAMPLES, 14TH DAY $(M+m, N=16)$

\begin{tabular}{l|c|c|}
\multirow{2}{*}{$\begin{array}{l}\text { Investigated } \\
\text { organ }\end{array}$} & \multicolumn{2}{|c}{ Test readings } \\
\cline { 2 - 3 } $\begin{array}{c}\text { Weight of the } \\
\text { organ, g }\end{array}$ & $\begin{array}{c}\text { Relative mass, } \\
\text { g } / 100 \text { g }\end{array}$ \\
\hline Brain & $1,793+0,075$ & $0,855+0,008$ \\
\hline Heart & $0,675+0,019$ & $0,323+0,008$ \\
\hline Liver & $6,942+0,290$ & $3,313+0,035$ \\
\hline Kidneys & $1,262+0,048$ & $0,603+0,008$ \\
\hline Adrenal glands & $0,033+0,001$ & $0,016+0,001$
\end{tabular}

TABLE 7. SURVIVAL RATES OF EXPERIMENTAL ANIMALS AFTER SINGLE INTRAPERITONEAL INJECTION OF $0.06 \%$ SODIUM HYPOCHLORITE SOLUTION, 14TH DAY

\begin{tabular}{l|c|c|c|}
$\begin{array}{l}\text { Experiment } \\
\text { conditions }\end{array}$ & $\begin{array}{c}\text { Number of } \\
\text { animals }\end{array}$ & $\begin{array}{c}\text { Injected } \\
\text { volume }\end{array}$ & $\begin{array}{c}\text { Dead / total } \\
\text { animals }\end{array}$ \\
& $\mathrm{n}=6$ & $1 / 10 \mathrm{CBV}$ & $0 / 6$ \\
$0,06 \% \mathrm{NaOCl}$ & $\mathrm{n}=6$ & $1 / 5 \mathrm{CBV}$ & $0 / 6$ \\
solution & $\mathrm{n}=6$ & $1 / 2 \mathrm{CBV}$ & $0 / 6$ \\
& $\mathrm{n}=6$ & $1 \mathrm{CBV}$ & $0 / 6$ \\
$\begin{array}{l}\text { Control group } \\
\text { (0,9\% NaOCl } \\
\text { solution) }\end{array}$ & $\mathrm{n}=6$ & $2 \mathrm{CBV}$ & $0 / 6$ \\
\hline
\end{tabular}

a volume of $0.5-2$ circulated blood volume (CBV) have been injected to detached rats (30 animals) intraperitoneally (comparison group). The animals were being observed for 14 days, paying attention to the appearance, behavior, and degree of manifestation of symptoms of intoxication. Studies have shown that a single application of dressings for 4 hours did not lead to changes in animal behavior, food and water consumption, did not cause changes in the relative mass of internal organs compared with the control group (Table 6). With intraperitoneal injection of sodium hypochlorite, no fatal cases have been observed during the entire observation period, too (Table 7).
Fig. 6. Condition of an uninfected wound on the skin of the laboratory rat before application of the test sample

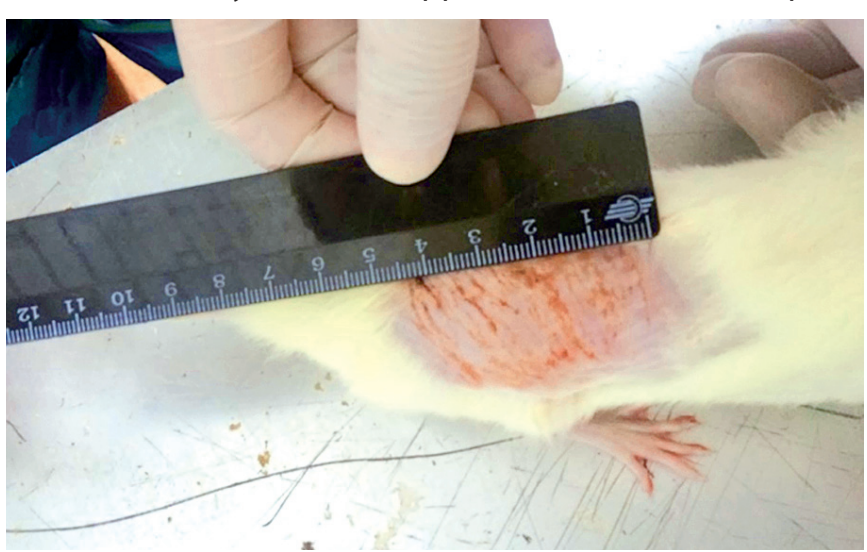

To investigate the regenerative activity of test samples of chlorine-active polymers on laboratory rats the Efimov's method has been used. The wounds were being made with a scalpel by stencil on a specially prepared surgical field. The average wound area was $695.5 \mathrm{~mm}^{2}$. In the initial state, the wounds of the animals presented a moist patch that excreted the ichor (Fig. 6).

To the animals of the experimental group, dressings were being applied each day on the wound surfaces twice daily for 30 minutes daily during 14 days. Animals from the comparison group were being applied with standard gauze dressings moistened with $0.06 \%$ sodium hypochlorite solution. In the control group, no treatment were being performed. The rate of wound healing has been determined by Popova's test based on the measurement of wound area in dynamics. It has been found that in the first 4 days there were no differences in the regenertion of damaged skin between all groups of animals. At day 10 and day 14, the wound epithelialization rate of the animals of the experimental group was significantly higher than in the control group (Table 8, Fig. 7).

As can be seen, the wound healing rate with the application of dressings with immobilized active chlorine is 1.4-1.5 times higher than in the control group. In the comparison group, similar results have been obtained - the wound area on the 14 th day decreased by an average of $65 \%$. Pathomorphological studies have shown that destructive changes in tissues do not occur with applications of immobilized sodium $\mathrm{N}$-chlorosulfonamide. At the same time, pathological changes

TABLE 8. INFLUENCE OF POLYMER SODIUM N-CHLOROSULFONAMIDES ON THE SIZE OF WOUND SURFACE AREA OF RATS, $M \pm m$

\begin{tabular}{|c|c|c|c|c|c|c|c|}
\hline \multirow{3}{*}{ Experiment conditions } & \multicolumn{7}{|c|}{ Observation period, days } \\
\hline & \multirow{2}{*}{$\begin{array}{c}\begin{array}{c}\text { Initial } \\
\text { state }\end{array} \\
\text { average } \\
\text { wound } \\
\text { area, } \mathrm{cm}^{2}\end{array}$} & \multicolumn{2}{|c|}{4 days } & \multicolumn{2}{|c|}{10 days } & \multicolumn{2}{|c|}{14 days } \\
\hline & & $\begin{array}{l}\text { average } \\
\text { wound } \\
\text { area, } \mathrm{cm}^{2}\end{array}$ & $\%$ change & $\begin{array}{c}\text { average } \\
\text { wound } \\
\text { area, } \mathrm{cm}^{2}\end{array}$ & $\%$ change & $\begin{array}{l}\text { average } \\
\text { wound } \\
\text { area, } \mathrm{cm}^{2}\end{array}$ & $\%$ change \\
\hline Control & $6,8 \pm 0,7$ & $6,4 \pm 0,6$ & $-5,8$ & $5,1 \pm 0,5$ & -25 & $3,7^{*} \pm 0,4$ & -46 \\
\hline $\begin{array}{l}\text { Test sample of immobilized sodium } \\
\mathrm{N} \text {-chlorosulfonamide, } 6 \% \text { active chlorine }\end{array}$ & $7,1 \pm 0,7$ & $6,5 \pm 0,6$ & $-8,4$ & $4,3^{*} \pm 0,4$ & -39 & $2,3^{*} \pm 0,2$ & -68 \\
\hline $\begin{array}{l}\text { Test sample of immobilized N, N-dichloro- } \\
\text { sulfonamide, } 9 \% \text { active chlorine }\end{array}$ & $7,0 \pm 0,7$ & $6,3 \pm 0,6$ & $-10,0$ & $4,4^{*} \pm 0,4$ & -37 & $2,5^{*} \pm 0,2$ & -64 \\
\hline
\end{tabular}

Notes: * $-p<0.05$ relative to baseline indicators 


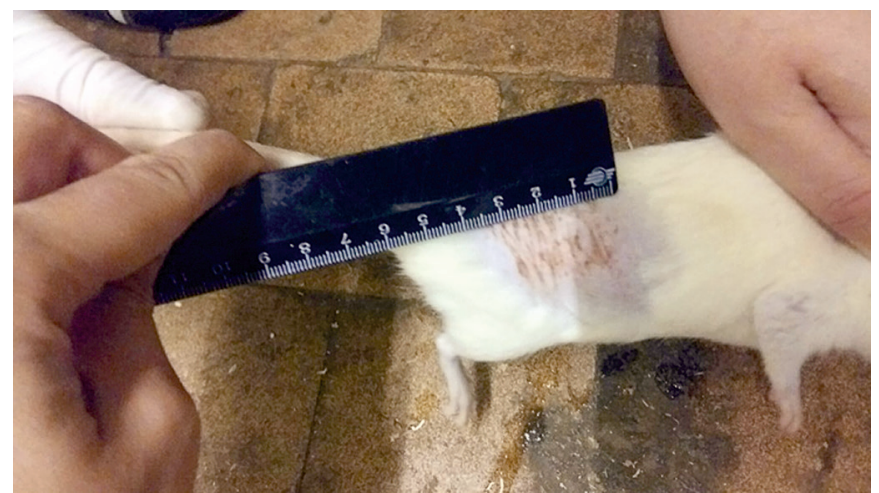

Fig. 7. Condition of uninfected skin wound of laboratory rat after 14 days of application of the tested samples.

in the histoarchitectonics of the epidermis have been detected with the use of $\mathrm{N}, \mathrm{N}$-dichlorosulfonamide. This is due to the higher oxidation properties of the latter samples. Probably, such dressings should be used only with very intense contamination (or inflammation) of the wound surface.

In the last phase of our research, the effect of synthesized polymers on simulated infected wounds have been investigated. Given our previous experience, we have only tested the sodium $\mathrm{N}$-chlorosulfonamide immobilized on non-woven fabric. For this purpose, 34 laboratory rats have been distributed as follows: 3 experimental groups of 6 animals; comparison group with reference $\operatorname{drug}$ ( $0.06 \%$ solution of sodium hypochlorite) of 6 animals; control group of 10 animals. The suture impregnated with a daily culture of S. aureus ATCC 6538 (dose 109 CFU/ml) have been sewed in to all rats by the method [50]. On the 3rd day after infection the dressings have been applied on the wounds of the animals of the experimental group for a period of 4-12 hours (Table 8). By this time, the symptoms of infection were clearly expressed. Animals from the comparison group were being applied with gauze dressings impregnated with a solution of the reference drug. The intensity of local clinical symptoms of inflammation have been observed. Bacteriological control of inflammatory processes have been carried out by the method [51]. It has been found that in the experimental group the animals began to recover faster than in the control group, and the recovery rate was directly proportional to the time of

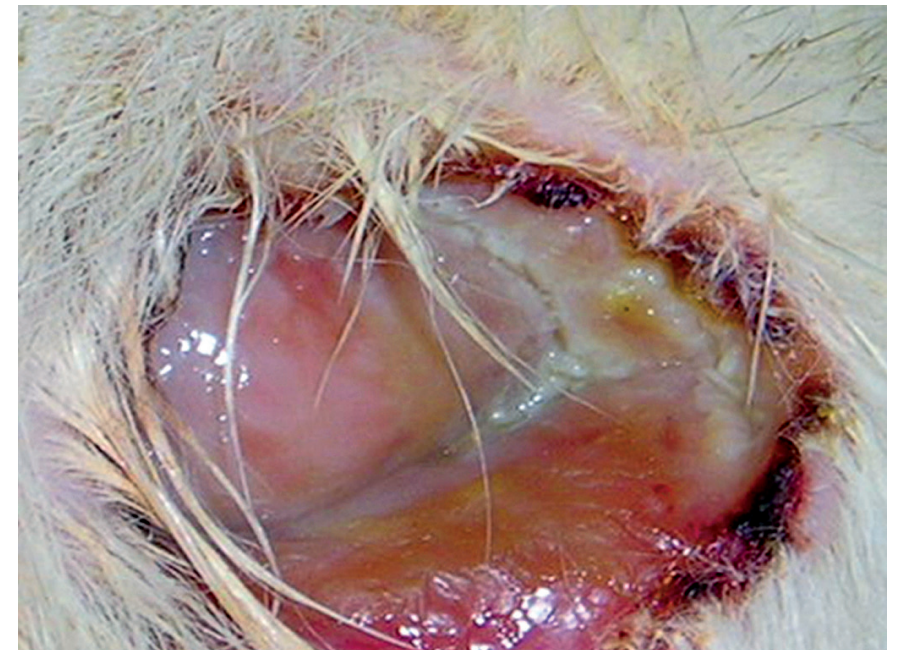

Fig. 8. The wound surface of the rat from the control group (14th day)

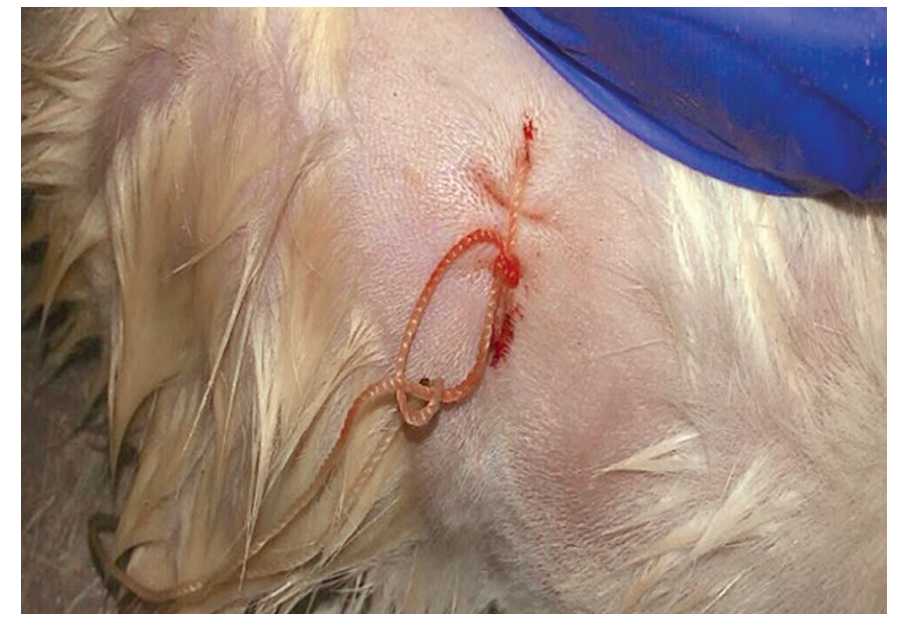

Fig. 9. The infected wound surface of the rat from the experimental group after 7 days of application of the tested samples 12 hours per day

dressing application (Table 9). No animal deaths have been observed in any of these subgroups. In the comparison group, wound healing started at the same time, but full recovery has come later. In the control group recovery of animals was much

TABLE 9. INTENSITY PROGRESS OF LOCAL MANIFESTATIONS OF INFLAMMATION IN STAPHYLOCOCCAL INFECTION OF ANIMALS IN THE EXPERIMENTAL GROUPS, COMPARISON GROUP AND CONTROL GROUP

\begin{tabular}{|c|c|c|c|c|c|c|c|c|c|c|c|c|c|c|c|c|c|}
\hline \multirow{3}{*}{$\begin{array}{l}\text { Animal groups and } \\
\text { application time }\end{array}$} & \multirow{3}{*}{$\begin{array}{c}\text { Number } \\
\text { of } \\
\text { animals }\end{array}$} & \multirow{3}{*}{ Died } & \multicolumn{5}{|c|}{$\begin{array}{l}\text { Progress of purulent-necrotic } \\
\text { process followed by recovery }\end{array}$} & \multirow{2}{*}{\multicolumn{10}{|c|}{$\begin{array}{l}\text { Number of animals with a healing period } \\
\text { wounds per day: }\end{array}$}} \\
\hline & & & \multirow[t]{2}{*}{ Total } & \multicolumn{4}{|c|}{ including with intensity } & & & & & & & & & & \\
\hline & & & & ++++ & +++ & ++ & + & 7 & 8 & 9 & 10 & 11 & 12 & 13 & 14 & 15 & 16 \\
\hline 4 hours & 6 & 0 & 6 & 2 & 2 & 1 & 1 & 0 & 0 & 2 & 1 & 0 & 1 & 2 & 0 & 0 & 0 \\
\hline 8 hours & 6 & 0 & 6 & 3 & 1 & 0 & 2 & 0 & 1 & 2 & 0 & 2 & 1 & 0 & 0 & 0 & 0 \\
\hline $\begin{array}{l}8 \text { hours } 0,06 \% \text { sodium } \\
\text { hypochlorite solution }\end{array}$ & 6 & 0 & 6 & 3 & 1 & 1 & 1 & 0 & 1 & 2 & 1 & 1 & 0 & 0 & 1 & 0 & 0 \\
\hline 12 hours & 6 & 0 & 6 & 1 & 3 & 1 & 1 & 2 & 3 & 1 & 0 & 0 & 0 & 0 & 0 & 0 & 0 \\
\hline Control & 10 & 1 & 9 & 3 & 3 & 1 & 2 & 0 & 0 & 0 & 0 & 1 & 1 & 2 & 1 & 2 & 2 \\
\hline
\end{tabular}

Notes. Intensity of local clinical symptoms: ++++ - hyperemia and swelling of the tissue surrounding the wound are pronounced; abundant detachment; +++ - hyperemia and edema, expressed moderately; less abundant, serous, hemorrhagically separated; ++ - hyperemia and edema, poorly expressed; wound surface covered with scab; + - slight hyperemia around the wound covered with a dry scab. 
TABLE 10. LOGARITHM OF THE AVERAGE NUMBER OF STAPHYLOCOCCI DETECTED IN EXCRETIONS FROM THE WOUND SURFACE IN RATS DEPENDING ON THE CONDITIONS OF THE EXPERIMENT

\begin{tabular}{|c|c|c|c|c|c|c|c|c|c|}
\hline \multirow{3}{*}{$\begin{array}{l}\text { Experiment conditions } \\
\text { and application period per day }\end{array}$} & \multirow{3}{*}{$\begin{array}{l}\text { Number } \\
\text { of animals }\end{array}$} & \multicolumn{8}{|c|}{ Terms of the study after application (day): } \\
\hline & & 1 & 2 & 3 & 4 & 5 & 6 & 7 & 8 \\
\hline & & \multicolumn{8}{|c|}{ Logarithm of the average number of staphylococci } \\
\hline Test sample application, 4 hours & 6 & 5,6 & 5,3 & 5,0 & 5,0 & 4,9 & 4,5 & 4,0 & 3,8 \\
\hline Test sample application, 8 hours & 6 & 5,5 & 5,2 & 5,0 & 4,5 & 4,0 & 3,9 & 3,7 & 3,2 \\
\hline Sodium hypochlorite $0,06 \%$ solution, 4 hours & 6 & 5,6 & 5,5 & 5,2 & 4,8 & 4,5 & 4,2 & 4,0 & 3,7 \\
\hline Test sample application, 12 hours & 6 & 5,3 & 5,0 & 4,5 & 4,1 & 3,7 & 3,2 & 2,9 & 2,5 \\
\hline Control & 10 & 6,6 & 6,9 & 6,5 & 6,1 & 6,1 & 5,9 & 5,3 & 4,8 \\
\hline
\end{tabular}

slower, one rat died from the staphylococcal sepsis. The wound condition of the rats from the control and experimental group on the 14th day after the infection is showed on Fig. 8 and Fig. 9 correspondingly.

Table 10 shows the results of bacteriological control of wound exudate on the content of staphylococci.

As can be seen, under the dressings made of immobilized $\mathrm{N}$-chlorosulfonamide as well as under those which are impregnated with sodium hypochlorite solution, the number of pathogenic staphylococci is approximately the same and 4-10 times less than in the control group [52].

Thus, it has been experimentally proved that the use of synthesized polymers with immobilized active chlorine is nontoxic and promotes healing of both uninfected and infected wounds.

\section{CONCLUSIONS}

The realized complex of researches convincingly has proved the possibility of effective application of new polymeric materials with immobilized active chlorine for express disinfection and storage of water, rapid obtaining of concentrated high-purity antiseptic chlorine-active solutions, as well as for disinfection and treatment of open wounds when using them as a component of medical dressing. High stability and non-toxicity of such materials have been proved, too. Industrial production of these new materials can be implemented in Ukraine on existing equipment and does not require significant investment.

\section{THE PERSPECTIVES OF FURTHER INVESTIGATIONS}

Taking into account preliminary data about the release of hypochlorous acid from the staple forms of synthesized polymers when passing through them chemically and biologically polluted air, it is advisable to study the possibility of their use in air purification systems. We will be developing systems for the rapid disinfection of water based on the immobilized forms of active chlorine. The design of a medical antiseptic dressing containing non-woven forms of immobilized chlorosulfonamides requires thorough development. To be widely used, such dressings must undergo final clinical trials.

\section{ACKNOWLEDGEMENTS}

The work has been carried out with the financial support of the Dnipropetrovsk Regional State Administration (within «Young Scientists for Dnipro Region» contest), the Dnipro City Council (within «InnoDnipro» contest), the Noosphere Ventures company (within the «Vernadsky Challenge» contest). The authors are especially grateful to Sanofi-Aventis Ukraine and National Academy of Medical Sciences of Ukraine for supporting the project at the «Sanofi Award for young scientists for research in medicine» contest.

\section{СПИСОК ВИКОРИСТАНИХ ДЖЕРЕЛ}

1. Spaulding E. Chemical disinfection of medical and surgical materials. Disinfection, sterilization and preservation; ed. C.A. Lawrence, S. S. Block. Philadelphia; 1968; P. 517-31.

2. Favero NS, Bond WW. Sterilization, disinfection and antisepsis in the hospital. Manual of Clinical Microbiology. 5th ed. Am Soc for Microbiol.: Washington, 1991; P. 183-200.

3. Fedorova LS, Arefeva LI, Putintseva LS, Veromkovich NA. Sovremennye sredstva dezinfektsii i dezinsektsii. Kharakteristika, naznachenie, perspektivy [Modern facilities for disinfection and disinsection] Meditsina i zdravookhranenie. Obzornaya inform. 1991; 2: 3-25. (in Russ.)

4. Demain AL, Sanchez S. Antibiotics: Current Innovations and Future Trends Norfolk: Caister Academic; 2015.430 p. DOI: $10.1002 /$ cmdc.201500099.
5. Samarin DV. Antibiotikorezistentnost [Antibiotic resistivity]. Therapia. Ukr med visnyk. 2009; 12: 43-5. (in Russ.).

6. Wallum TE, Yun HE, Rini EA, Carter K, Guymon $\mathrm{CH}$, Akers $\mathrm{KS}$, et all. Pathogens present in acute mangled extremities from Afghanistan and subsequent pathogen recovery. Mil Med. 2015 Jan 20;180(1): 97-103. DOI: 10.7205/ milmed-d-14-00301.

7. Romanova YuM, Didenko LV, Tolordava ER, Gintsburg AL. Bioplenki patogennykh bakteriy i ikh rol v khronizatsii infektsionnogo protsessa. Poisk sredstv borby s bioplenkami. [Biofilms of pathogenic bacteria and their role in the chronicity of the infectious process. Search for biofilm control agents.]. Annals of the Russian academy of medical sciences, 2011, № 10. P.31-39. (in Russ.).
8. Pidot SJ, Wei Gao, Buultjens AH, Monk IR, Guerillot R, Carter GP, Lee JY, at al. Increasing tolerance of hospital Enterococcus faecium to handwash alcohols. Sci Transl Med., 2018 Aug 01; 10(452):6115. DOI:10.1126/scitranslmed. aar6115.

9. Adegoke AA, Faleye AC, Gulshan S, Stenström TA Antibiotic Resistant Superbugs: Assessment of the Interrelationship of Occurrence in Clinical Settings and Environmental Niches. Molecules. 2016 Dec 27;22(1):29. DOI: 10.3390/molecules 22010029 .

10. WHO global strategy for containment of antimicrobial resistance. Geneva: World Health Organization; 2001. Available from: https://www. who.int/drugresistance/WHO_Global_Strategy_English.pdf. 
11. Berlin Declaration on Antimicrobial Resistance - Global Union for Antibiotics Research and Development (GUARD), Agreed by G7 Health Ministers in Berlin 2015. Available from: http://www. g7.utoronto.ca/healthmins/2015-berlin.html.

12. Bahir VM, Leonov BI, Panicheva SA, Priluckij VI, SHomovskaya NYU. Khimicheskiy sostav i funktsionalnye svoystva khlorsoderzhashchikh dezinfitsiruyushchikh rastvorov [Chemical composition and functional properties of chlorine-containing disinfectant solutions]. Journal of new medical technologies. 2003:4:50-9 (in Russ.).

13. Sakarya S, Gunay N, Karakulak M, Ozturk B, Ertugrul B. Hypochlorous acid: An ideal wound care agent with powerful microbicidal, antibiofilm, and wound healing potency. Wounds-Compend Clin. Res. Pract. 2014 Nov; 26: 342-50. Available from: https://pdfs.semanticscholar.org/ a02f/f548c3f03ce1c93cf96459072315ec388b31. pdf? ga $=2.193258925 .1864744178 .1571068723$ 1126994685.1568662076

14. Crew J, Najafi-Tagol K, Najafi R, Debabov D, Noorbakhsh C, Shiau T, Wang L, inventors; Novabay Pharmaceuticals, assignee. Method of inactivating toxins using oxidative chlorine species. United States patent 20160331779A1. 2015 Nov 5. Available from: https://patents. google.com/patent/US20160331779A1/en

15. Kosinets $A N$, Frolova AV, Bulavkin VP Okulich VK. Antibiotikorezistentnost. Novye vozmozhnosti antibakterialnogo vozdeystviya [Antibiotic resistivity. New opportunities of antibacterial effect]. Vestnik VGMU. 2014;13(2):70-7 (in Russ).

16. Weiss SJ, Klein R, Slivka A, Wei M. Chlorination of Taurine by Human Neutrophils. J Clin Invest. 1982 Sept 1;70(3):598-607. Available from: https://pdfs.semanticscholar.org/c96f/ 4c176151655a7e051 efbe056766cae37a8b2.pdf.

17. Ivanov VK, Belenkiy GZ, Snezhko ZI, inventors. Ivanov VK, Belenkiy GZ, Snezhko ZI, assignee. Dezintoksikatsionnyy infuzionnyy rastvor «Neoreodez» [Detoxificative infusion solution «Neoreodez»]. Russian Federation patent №2488382. 2012 Feb 7. (in Russ).

18. Grinberg VA, Skundin AM, Khokhryakov $Y B$, inventors. Medec LTD, assignee. Sposob i ustroystvo dlya polucheniya vysokochistykh rastvorov gipokhlorita natriya meditsinskogo naznacheniya [Method and device for producing high-purity sodium hypochlorite solutions for medical purposes]. Russian Federation patent №2110999. 1997 Feb 21. (in Russ.)

19. Crew JR, Varilla A, Allandale R III, Abdul $R S$, Debabov $D$. Treatment of acute necrotizing fasciitis using negative pressure wound therapy and adjunctive neutrophase irrigation under the foam. Wounds. 2013 Oct;25(10):272-7. Available from: https://pdfs. semanticscholar.org/44ee/9b62a589104cd-

$1980 \mathrm{cb} 7635$ ecdf4f80d48da.pdf? $\mathrm{ga}=.12583479 .1864744178 .1571068723$ 1126994685.1568662076

20. Robins L, Meyers C, Milici J, Williams J, Robison R. Efficacy testing of $\mathrm{HOCl}$ as a disinfectant for high-risk HPV. In: 5th International Conference on Prevention\&Infection Control (ICPIC 2019) [Internet]; 2019 Sept 10-13; Geneva. Geneva: BMC; 2019 Sept 09 [cited 19 Aug 2019]. Available from: https://www.ncbi.nlm.nih.gov/ pmc/articles/PMC6737605/.

21. Del Rosso JQ, Bhatia N. Status report on topical hypochlorous acid: Chemical relevance of specific formulations, potential modes of action, and study outcomes. J.Aesthet Derma- tol. 2018 Nov 01;11(11):36-9. Available from: https://www.ncbi.nlm.nih.gov/pmc/articles/ PMC6303114/.

22. Dvornikov VM. Novyy antiseptik «Doktor chistoteloff» s krovoostanavlivayushchey aktivnostyu [New antiseptic «Doctor Chistoteloff» with hemostatic activity]. Delo zhizni. 2015;4(4):18-9.

23. Kiamco MM, Zmuda HM, Mohamed A, Call DR Raval YS, Patel $R$, et al. Hypochlorous-Acid-Generating Electrochemical Scaffold for Treatment of Wound Biofilms. Scientific Reports. 2019;9:2683. DOI: 10.1038/s41598-019-38968-y.

24. Nakamura Y. High polymers containing free functional groups. VII. Insoluble resins containing sulfonamide, sulfochloramide, or sulfodichloramide group. J. Chem. Soc. Japan: Ind. Chem. Sect. 1954;57:818-9.

25. Emerson DW., Shea DT, Sorensen EM. Functionally Modified Poly (styrene-divinylbenzene). Preparation, Characterization and Bactericidal Action. Ind. Eng. Chem. Prod. Res. Dev. 1978;17(3):269. DOI: 10.1021/i360067a019

26. Emerson DW. Polymer-bound active chlorine: disinfection of water in a flow system. Polymer supported reagents. 5. Ind. Eng. Chem. Res. 1990 March 1;29(3):448-50. DOI: 10.1021/ ie00099a022.

27. Bogochek R, Kotsiolek-Balyaveyder E. Kationity s khloriruyushchimi, okislitelnymi i bakteritsidnimi svoystvami [Cation exchangers with chlorinating, oxidizing and bactericidal properties]. Vysokomolekulyarnye soedineniya. 1987;A(11):2346-52. (in Russ).

28. Ociński D, Stanisławska E, Kociolek Balawejder E. Redox Polymer with N,N-Dichlorosulfonamide Functional Groups as Arsenite Oxidant in Aqueous Solutions. Applied Polymer Science. 2014 Oct 18;132(9):41552-59.

DOI: 10.1002/app.41552

29. Bogoczek R, Kociolek-Balawejder E, Stanisławska E. Macromolecular N-Chlorosulfonamide as an Oxidant for Residual Nitrites in Aqueous Media. Ind. Eng. Chem. Res. 2005 March 16;44(23):8530-34. DOI: 10.1021/ ie040267x.

30. Bogoczek R, Kociolek-Balawejder $E$ Stanislawska E, Zabska A. Using macroporous $\mathrm{N}$-chlorosulfonamide S/DVB copolymer as an aid to iron removal from water. Pure Appl. Chem. 2007 Jan 8; 79(9):1491-1503. DOl:10.1351/ pac200779091491.

31. Gang Sun, Xiangjing Xu, inventors; University Of California, assignee. Durable and regenerable microbiocidal textiles. United States patent 5882357A. 1999 March 16. Available from: https://patents.google.com/patent/ CA2265851C/es.

32. Sun $X$, Cao Z, Porteous $N$, Sun $Y$. Amine, Melamine, and Amide N-Halamines as Antimicrobial Additives for Polymers. Ind EngChem Res. 2010:49(22):11206-13. DOl: 10.1021/ie101519u.

33. Sun Yu, Luo J, inventors; Board of pegents, the University of Texas System, assignee. Compositions and methods for making and using acyclic $\mathrm{N}$-halamine- based biocidal polymeric materials and articles. United States patent 8486428. 2013 Jul 16. Available from: https://patents.google. com/patent/WO2007126775A2.

34. Maddah B, Azimi M. Preparation of $\mathrm{N}, \mathrm{N}-\mathrm{di}-$ chloropolystyrene sulfonamide nanofiber as a regenerable self-decontaminating material for protection against chemical warfare agents.
Int. J. Nano Dim. 2012 Spring; 2(4):253-9. DOI: 10.7508/IJND.2011.04.006.

35. Maddah B, Azimi M, Imani S, Zand AM. Investigation on decontaminating efficiency of $\mathrm{N}$ $\mathrm{N}$-dichloropolystyrene sulfonamide nanofibers against pathogenic bacteria of human body flora. Asian J of Chemistry. 2013;25(1):217-9. DOI: 10.14233/ajchem.2013.12896.

36. Soldatov VS, Pokrovskaya Al, Martsinkevich RV. Voloknistye sulfokationity na osnove poli propilena [Polypropylene-based fibrous sulfocation exchangers]. Journ Appl Chem. 1984;57(9):203034. (in Russ.).

37. Soldatov V, Pawlowski L, Shunkevich A, Wasag $H$. New materials and technologies for environmental engineering: synthesis and struc ture of ion exchange fibers.Lublin: Liber Duo Color; 2004. 130 p.

38. Burmistrov KS, Toropin VN, Ryabenko VV Kremenchutskiy GN, Balalaev AK. Emissiya aktivnogo khlora iz immobilizovannykh N-khlorsulfonamidov [Emission of active chlorine from immobilized N-chlorosulfonamides]. Voprosy Khimii i Khimicheskoi Tekhnologii. 2014;3:30-6. (in Russ.).

39. Toropin VN, Burmistrov KS, Murashevich BV, Kremenchutskiy GN. Sintez i emissiya aktivnogo khlora iz immobilizovannykh N-khlor-N-alkilsulfonamidov [Synthesis and emission of active chlorine from immobilized N-chloro-N-alkylsulfonamides.]. Science Rise: Pharm. Science. 2016:4(21):22-30. (in Russ.). DOI: 10.15587/23138416.2016 .66881 .

40. Burmistrov KS, Toropin VN, Kremenchutskiy GN, Polikarpov AP, Shunkevich AA. Novyy khlorvydelyayushchiy material shirokogo naznacheniya: Stroenie i svoystva [New chlorine-releasing material for a wide range of purposes: Structure and properties]. Problems of Biol., Med. and Pharm. Chem. 2016;19(12):10-4. (in Russ.).

41. GOST 18190-72 Mezhgosudarstvennyy standart. Voda pitevaya. Metody opredeleniya soderzhaniya ostatochnogo aktivnogo khlora [Interstate standard. Drinking water. Methods for determining the content of residual active chlorine]. Moskva. Standartinform. 2009. (in Russ.)

42. Nagl M, Larcher C, Gottardi W. Activity of $\mathrm{N}$-chlorotaurine against herpes simplex- and adenoviruses. Antiviral Res. 1998 Apr;38(1):25-30. DOI: 10.1016/s0166-3542(98)00005-9.

43. Gottardi W, Nagl M. N-chlorotaurine, a natural antiseptic with outstanding tolerability. J of Antimicrobial Chemotherapy. 2010 March;65(3):399-409. DOI: 10.1093/jac/dkp466.

44. Najafi R, Wang L, Bassiri M, Yang J, inventors; Novabay Pharmaceuticals, assignee. Physiologically balanced, ionized, acidic solution and methodology for use in wound healing. United States patent 7393522B2. $2000 \mathrm{Dec} 12$. Available from: https://patents.google.com/ patent/WO2004012748A1/da

45. Davies JM, Horwitz DA, Davis KJ. Inhibition of collagenase activity by $\mathrm{N}$-chlorotaurine, a product of activated neutrophils. Arthritis Rheum. 1994 March 3;37:424-7. DOI: 10.1002/ art.1780370317.

46. Toropin VN, Surmasheva YeV, Romanenko LI Izuchenie antimikrobnykh svoystv immobilizovannykh voloknistykh N-khlorsulfonamidov [The study of the antimicrobial properties of immobilized fibrous $\mathrm{N}$-chlorosulfonamides]. Current issues in pharmacy and medicine: science and practice. 2016;3(22):54-8. (in Russ.). DOI: 10.14739/2409-2932.2016.3.77993. 
47. Toropin VN, Burmistrov KS, Surmasheva YeV, Romanenko LI. Izuchenie antimikrobnykh svoystv immobilizovannykh voloknistykh $\mathrm{N}, \mathrm{N}$-dikhlorsulfonamidov [The study of the antimicrobial properties of immobilized fibrous $\mathrm{N}, \mathrm{N}$-dichlorosulfonamides]. Science Rise: Pharm. Science. 2016;4(4):48-52. (in Russ.). DOI: 10.15587/2519-4852.2016.85905.

48. Toropin VM, Stepanskyi DO, Murashevych BV Kremenchutskyi HM, Burmistrov KS, Koshova IP. Mikrobiolohichni doslidzhennia immobilizovanoho N-khlorsulfonamidu na sopolimeri styrolu [Microbiological studies of immobilized $\mathrm{N}$-chlorosulfonamide on styrene copolymers]. Visnyk Vinnytskoho natsionalnoho medychnoho universytetu. 2018;22(2):289-92. (in Russ.). DOI: 10.31393/reports-vnmedical-2018-22(2)-11.
49. Sidorov KK. Vvedenie veshchestv $v$ zheludok $v$ trakheyu, pod kozhu, $v$ venu i drugie puti vvedeniya yadov laboratornym zhivotnym. Metody opredeleniya toksichnosti i opasnosti khimicheskikh veshchestv [The injection of substances into the stomach, trachea, under the skin, into a vein and other routes of injection of poisons to laboratory animals. Methods for determining the toxicity and hazard of chemicals]. Moscow, 1976. 87 p. (in Russ.).

50. Mazur IA, Mamchur VI, Podpletnyaya YeA inventors; $S M O$ «Pharmatron» (UA), assignee. Ranozazhivlyayushchee i protivomikrobnoe sredstvo [Wound healing and antimicrobial agents]. Russian Federation patent №2317818. 2008 Feb 27. (in Russ.).
51. Ob unifikatsii mikrobiologicheskikh metodov issledovaniya, primenyaemykh $v$ kliniko-diagnosticheskikh laboratoriyakh LPU [About the unification of microbiological research methods used in clinical diagnostic laboratories of hospitals]. Decree of Ministry of Health of USSR №535, 22.04.1985

(in Russ.).

52. Dronov SN, Mamchur VI, Koshevaya IP Stepanskiy DA, Kremenchutskiy GN Toropin VN, ta in. Novye perevyazochnye materialy prolongirovannogo deystviya [New wound dressings of prolonged action]. Zaporozhskiy meditsinskiy zhurnal. 2019;21(3(114)):365-72. (in Russ.).

DOI:10.14739/2310-1210.2019.3.169189.

\section{INFORMATION ABOUT AUTHORS}

\section{DNIPROPETROVSK MEDICAL ACADEMY OF THE MINISTRY OF HEALTH OF UKRAINE}

Dmytro O. Stepanskyi, Dr. Sci. (Medicine), Head of the Chair of the microbiology, virology, immunology and epidemiology

Henadii M. Kremenchutskiy, Dr. Sci. (Medicine), Prof. of the Chair of the microbiology, virology, immunology and epidemiology

Bohdan V. Murashevych, Cand. Sci. (Chemistry), Associate professor of the biochemistry and medical chemistry department

\section{UKRAINIAN STATE UNIVERSITY OF CHEMICAL TECHNOLOGY}

Kostiantyn S. Burmistrov, Dr. Sci. (Chemistry), Professor of the organic substances and pharmaceuticals department

Volodymyr M. Toropin, graduate student of the organic substances and pharmaceuticals department

Mykola V. Toropin, leading engineer of the Research Institute of Galvanochemistry of the University

\section{PEЗЮME}

\section{Новые формы иммобимизованного активного хлора и перспективы их использования в медицине}

\section{В. Н. Торопин ${ }^{2}$, Б. В. Мурашевич1,20, Д. А. Степанский', Н. В. Торопин ${ }^{2}$, Г. Н. Кременчуцкий', К. С. Бурмистров ${ }^{2}$}

1 Государственное учреждение «Днепропетровская медииинская академия МОЗ Украины», ул. Владимира Вернадского, 9, Днипро 49044, Украина

2 Государственное высшее учебное заведение «Украинский государственный химикотехнологический университет», просп. Гагарина, 8, Днипро 49005, Украина

Поиск новых эффективных средств для борьбы с болезнетворными микроорганизмами является одной из важнейших

\section{ВІДОМОСТІ ПРО АВТОРІВ}

\author{
ДНІПРОПЕТРОВСЬКА \\ МЕДИЧНА АКАДЕМІЯ МОЗ УКРАЇНИ
}

Степанський Дмитро Олександрович - завідувач кафедри мікробіології, вірусології, імунології та епідеміології, д.м.н.

Кременчуцький Геннадій Миколайович - професор кафедри мікробіології, вірусології, імунології та епідеміології, д.м.н.

Мурашевич Богдан Валерійович - доцент кафедри біохімії та медичної хімії, к. хім. н.

\section{УКРАЇНСЬКИЙ ДЕРЖАВНИЙ \\ ХІМІКО-ТЕХНОЛОГІЧНИЙ УНІВЕРСИТЕТ}

Бурмістров Костянтин Сергійович - професор кафедри технології органічних речовин і фармацевтичних препаратів, д.хім.н.

Торопін Володимир Миколайович - аспірант кафедри технології органічних речовин і фармацевтичних препаратів

Торопін Микола Володимирович - провідний інженер науково-дослідного інституту гальванохімії

\section{PEЗЮME}

\section{Нові форми іммобілізованого активного хиору та перспективи іх застосування в меАицині}

\section{B. М. Торопін ${ }^{2}$, Б. В. Мурашевич1,2 Д. О. Степанський ${ }^{1}$, М. В. Торопін ${ }^{2}$, Г. М. Кременчуцький ${ }^{1}$, К. С. Бурмістров ${ }^{2}$}

${ }^{1}$ ДЗ «Дніпропетровська медична академія МОЗ України», вул. Володимира Вернадського, 9, Дніпро 49044, Україна

${ }^{2}$ ДВНЗ «Український державний хімікотехнологічний університет», просп. Гагаріна, 8, Дніпро 49005, Україна

Пошук нових ефективних засобів для боротьби з хвороботворними мікроорганізмами $є$ одним із найважливіших завдань сучасної медицини. Основною причиною необхідності таких 
задач современной медицины. Необходимость таких исследований продиктована тенденцией к увеличению устойчивости патогенных микроорганизмов к применяемым для этих целей соединениям, наблюдаемая в последние несколько десятилетий. Проблема развития «супербактерий» признана ведущими международными организациями глобальной угрозой для всего человечества. Чрезвычайно эффективными биоцидными средствами являются соединения активного хлора. Однако по ряду причин классические хлорактивные препараты (растворы гипохлорита натрия, хлорноватистой кислоты, хлорамины и т. п.) имеют ограниченное применение в медицине. Данная работа посвящена изучению свойств новых форм активного хлора. Разработана технология химической иммобилизации групп-доноров активного хлора на гранульные и волокнистые полимерные носители. Получены полимеры, содержащие 5-20\% активного хлора и отличающиеся высокой устойчивостью. Показано, что при контакте таких полимеров со средой, содержащей соли аммония или примеси белковой природы, происходит эмиссия активного хлора в количестве, эквивалентном содержанию таких примесей. Разработаны методики быстрого получения высокочистых растворов активного хлора (хлорноватистой кислоты, хлортаурина) путем активации данных полимеров специальными активаторами. Доказана высокая антимикробная активность таких растворов. Показано, что сами полимеры также проявляют высокую микробицидную активность. Исследована возможность применения волокнистых форм хлорактивных полимеров в качестве антимикробного компонента раневой повязки. Доказано отсутствие токсичности таких повязок. Показано, что наложение повязок на неинфицированные раны ускоряет процесс их заживления. Аппликация повязок на инфицированные раны препятствует развитию воспалительных процессов и значительно снижает количество патогенных микроорганизмов в раневых выделениях. Таким образом, синтезированные полимеры с иммобилизованным активным хлором перспективны для применения в системах дезинфекции воды, воздуха, обеззараживания больничных стоков, быстрого получения антисептических растворов, а также для изготовления антисептических раневых повязок пролонгированного действия, защищающих раны от вторичного инфицирования, что особенно актуально для военной медицины и медицины катастроф.

Ключевые слова: дезинфекция, антисептика, активный хлор, иммобилизация, антисептические растворы, антимикробная активность, репаративная активность, раневые повязки.

Для цитирования: Торопин $\mathrm{BH}$, Мурачевич БB, Степанский ДА, Торопин НВ, Кременчуикий ГН, Бурмистров КС. Новые формы иммобилизованного активного хлора и перспективы их использования в медицине. Журнал Национальной академии медицинских наук Украины. 2019;25(3):340-52

Статья поступила в редакцию 5 сентября 2019| Направлена на рецензирование 15 сентября 2019| Принята в печать 17 сентября 2019 досліджень є очевидна тенденція до збільшення стійкості патогенних мікроорганізмів до речовин, застосовуваних для зазначених вище цілей, яку спостерігаємо в останні кілька десятиліть. Проблема розвитку «супербактерій» визнана провідними міжнародними організаціями як глобальна загроза для людства загалом. Надзвичайно ефективними біоцидними засобами $\epsilon$ сполуки активного хлору. Однак через низку причин класичні хлорактивні препарати (розчини гіпохлориту натрію, гіпохлоритної кислоти, хлораміни і т. ін.) мають обмежене застосування в медицині. Ця праця присвячена вивченню властивостей нових форм активного хлору. Розроблено технологію хімічної іммобілізації груп-донорів активного хлору на гранульні й волокнисті полімерні носії. Отримано полімери, що містять 5-20 \% активного хлору та мають високу стійкість. Показано, що при контакті таких полімерів із середовищем, що містить солі амонію або домішки білкової природи, відбувається емісія активного хлору в кількості, еквівалентній змісту таких домішок. Розроблено методики швидкого отримання високочистих розчинів активного хлору (гіпохлоритної кислоти, хлортаурина) шляхом активації зазначених полімерів спеціальними активаторами. Доведено високу антимікробну активність таких розчинів. Показано, що самі полімери також виявляють високу мікробіцидну активність. Досліджено можливість застосування волокнистих форм хлорактивних полімерів як антимікробного компонента ранової пов'язки. Доведено відсутність токсичності таких пов'язок. Показано, що накладення пов'язок на неінфіковані рани прискорює процес їхнього загоєння. Аплікація пов'язок на інфіковані рани перешкоджає розвитку запальних процесів і значно знижує кількість патогенних мікроорганізмів у ранових виділеннях. Отже, синтезовані полімери з іммобілізованим активним хлором перспективні для застосування в системах дезінфекції води, повітря, знезараження лікарняних стоків, швидкого отримання антисептичних розчинів, а також для виготовлення антисептичних ранових пов'язок пролонгованої дії, які захищають рани від вторинного інфікування, що надзвичайно актуально передусім для військової медицини та медицини катастроф.

Ключові слова: дезінфекція, антисептика, активний хлор, іммобілізація, антисептичні розчини, антимікробна активність, репаративна активність, ранові пов'язки.

Для цитування: Торопін ВМ, Мурашевич БВ, Степанський ДО, Торопін МВ, Кременчуцький ГМ, Бурмістров КС. Нові форми іммобілізованого активного хлору та перспективи їх застосування в медицині. Журнал Національної академії медичних наук України. 2019;25(3):340-52

Стаття надійшла до редакції 5 вересня 2019 року | Направлена на рецензування 15 вересня 2019 року | Прийнята до друку 17 вересня 2019 року

\section{Мурашевич}

Богдан Валерійович murashevych.b@gmail.com 